NOTA / NOTE:

\title{
Primer registro del tiburón quelvacho negro, Centrophorus squamosus (Chondrichthyes: Centrophoridae) (Bonnaterrre), para el Caribe de Colombia
}

\section{First record of the leafscale gulper shark Centrophorus squamosus (Bonnaterre) (Chondrichthyes: Centrophoridae) in the Colombian Caribbean}

\author{
María del Pilar Parrado-Cortés ${ }^{1}$ and William Zubiría Rengifo ${ }^{2}$ \\ (iD) $0000-0002-4512-0546$. \\ ${ }^{1}$ Instituto de Investigaciones Marinas y Costeras (Invemar), Calle 25 No.2-55 Playa Salguero, Santa Marta, Colombia.maria.parrado@invemar.org.co. \\ ${ }^{2}$ Calle Madrid 20, 2 H Sanxenxo, Pontevedra, España.willizu@hotmail.com.
}

\section{RESUMEN}

e presenta el primer registro de Centrophorus squamosus para el Caribe colombiano. Esta especie es conocida por ocupar hábitats batipelágicos entre 145 y 4000 m de profundidad, y su característica principal es la forma y disposición de sus dentículos dérmicos.

El espécimen encontrado fue capturado con palangre cerca a Punta Polno, departamento de La Guajira. Esta es la primera evidencia de la ocurrencia de esta especie en aguas por fuera de la plataforma del Caribe colombiano.

PALABRAS CLAVE: Batipelágico, Dentículos dérmicos, Palangre, La Guajira.

\section{ABSTRACT}

$\mathrm{T}$ his article presents the first record of Centrophorus squamosus for the Colombian Caribbean. This species is known to occupy bathypelagic habitats between 145 and $4000 \mathrm{~m}$ depth; its main feature is the shape and arrangement of its dermal denticles. The specimen found was caught with longline near Punta Polno, La Guajira department. This is the first evidence of the occurrence of this species in Colombian Caribbean offshore waters.

KEYWORDS: Bathypelagic, Dermal denticles, Longline, La Guajira. 
La familia Centrophoridae (Chondrichthyes: Squaliformes) conocida como tiburones quelvachos o gulper sharks, se caracteriza por tener cinco hendiduras branquiales justo en la parte anterior de la aleta pectoral, presenta espiráculos grandes ubicados detrás de los ojos, dientes puntiagudos y una marcada diferencia entre las mandíbulas superior e inferior. Las dos aletas dorsales tienen en el margen anterior una espina larga, fuerte y estriada, ausencia de la aleta anal y una muesca subterminal en la aleta caudal (Compagno, 1984; Carpenter 2002). Actualmente, se reconocen dos géneros para esta familia, Deania y Centrophorus, el primero con 4 especies y el segundo con 15; algunas de las cuales, como es el caso de C. squamosus, fueron incluidas por Compagno dentro de la familia Squalidae en 1973 y 1984.

El género Centrophorus presenta una marcada diferencia entre las mandíbulas superior e inferior, en la primera presenta dientes como hojillas triangulares, estrechos, altos y de gran tamaño, mientras que en la segunda los dientes son bajos y anchos. Las puntas traseras de las aletas pectorales son cortas y presentan una forma que va de angular a alargada y agudamente puntuda. Mientras que las características diagnosticas que distinguen la especie $C$. squamosus de sus congéneres son: puntas traseras de las aletas pectorales libres y considerablemente angulares, no sobrepasan el origen de la espina de la primera aleta dorsal; los dentículos dérmicos presentan múltiples cimas laterales las cuales se aprecian con mayor claridad en etapa adulta (Compagno, 1984).

En primera instancia esta especie fue descrita por Bonnaterre en 1788 como Squalus squamosus de un ejemplar colectado en el Atlántico nororiental. Luego Krefft y Tortonese (1973a, 1973b) lo citan como Lepidorhinus squamosus, a partir de organismos provenientes del Atlántico nororiental y el Mediterráneo. Shirai (1983) la valida como Centrophorus squamosus con especímenes del noreste del mar de Japón y del mar de Ojotsk (Amaoka et al., 1983). En cuanto al Atlántico occidental, Cervigón y Alcalá (1999) registran su presencia en el Caribe venezolano con un espécimen capturado en las expediciones del F. Nansen, advirtiendo su dudosa identificación. Luego Compagno (Carpenter, 2002) vuelve a registrar la especie en el mismo punto afirmando la necesidad de una revisión debido a la posibilidad de una identificación inadecuada. Sáez y colaboradores (2010) citan la presencia de C. squamosus en el golfo de Ancud, Chile, Pacífico sur oriental y AcuñaMarrero et al. (2013) la mencionan de la Reserva Marina Galápagos en Ecuador.
The family Centrophoridae (Chondrichthyes: Squaliformes), which primarily contains gulper sharks, is characterized by the presence of five gill slits anterior to the pectoral fin, large spiracles behind the eyes, pointy teeth and a marked difference between the upper and lower jaws. Additionally, these sharks are characterized by a long, strong and striated spine in the anterior margin of each of the two dorsal fins, absence of an anal fin and presence of a subterminal notch in the caudal fin (Compagno, 1984; Carpenter 2002). Two genera are currently recognized, Deania and Centrophorus, the former containing four species and the latter containing 15, some of which, such as C. squamosus, were included by Compagno under the family Squalidae in 1973 and 1984.

The genus Centrophorus presents marked differences between the upper and lower jaws, the upper teeth being triangular, awl-like, narrow, tall and large, whereas the lowers are short and stout. The rear tips of the pectoral fins are short, angular to elongated and sharply pointed. The diagnostic features that distinguish $C$. squamosus from its other congeners include: the rear tips of the pectoral fins are free and considerably angular and do not extend beyond the origin of the spine of the first dorsal fin, and the dermal denticles have multiple lateral ridges, which can be seen more clearly in adulthood (Compagno, 1984).

This species was first described by Bonnaterre in 1788 as Squalus squamosus, based on a specimen from the northeastern Atlantic. Later, Krefft and Tortonese (1973a, 1973b) cited this species as Lepidorhinus squamosus, based on specimens from the northeastern Atlantic and Mediterranean Sea. In 1983, Shirai validated the species as Centrophorus squamosus based on specimens from the northeastern Sea of Japan and the Sea of Okhotsk (Amaoka et al., 1983). Cervigón and Alcalá (1999) recorded the presence of the species in the Venezuelan Caribbean in the western Atlantic based on a specimen captured during the expeditions of F. Nansen, but they noted a questionable identification. Compagno (Carpenter, 2002) again recorded the species at the same locality, stating the need for a revision due to the possibility of improper identification. Sáez and collaborators (2010) cited the presence of C. squamosus in the Gulf of Ancud, Chile, southeastern Pacific, and AcuñaMarrero et al. (2013) noted this species in the Galapagos Marine Reserve in Ecuador.

During an expedition in the Jarara exploratory drilling area of interest (AIPE- área de interés de perforación exploratoria), located in the Tayrona block, 
Durante la exploración realizada en el área de interés de perforación exploratoria (AIPE) Jarara ubicada en el bloque Tayrona, mar Caribe colombiano, a la altura de Punta Polno, La Guajira, se capturó un ejemplar macho de Centrophorus squamosus en $12^{\circ} 46^{\prime} 45.4^{\prime \prime} \mathrm{N} \mathrm{y} 71^{\circ} 36^{\prime} 00.8^{\prime \prime} \mathrm{O}$ (Figura 1a), a una profundidad que osciló entre 600 y 670 m, mediante un palangre vertical y anzuelo curvo No. 11. Este ejemplar se fijó en formol al 10\% durante el crucero, para luego ser preservado en etanol al $70 \%$. Su identificación se realizó con claves de Compagno (1984 y 2002). Finalmente, el tiburón se depositó en la colección de referencia del Instituto de Investigaciones Marinas y Costeras (Invemar), Santa Marta, Colombia como INV-PEC-9006.
Colombian Caribbean Sea, at the longitude of Punta Polno, La Guajira, a male specimen of Centrophorus squamosus was captured at $12^{\circ} 46^{\prime} 45.4^{\prime \prime} \mathrm{N} ; 7^{\circ} 36^{\prime} 00.8^{\prime \prime} \mathrm{W}$ (Figure 1a) between 600 and $670 \mathrm{~m}$ depth with a vertical longline and a size 11 curved hook. The specimen was fixed in $10 \%$ formaldehyde onboard for later preservation in $70 \%$ ethanol. The identification was based on the taxonomic keys by Compagno $(1984,2002)$. The shark was deposited in the reference collection of the Marine and Coastal Research Institute (Instituto de Investigaciones Marinas y Costeras - Invemar), Santa Marta, Colombia under the number INV-PEC-9006. a.

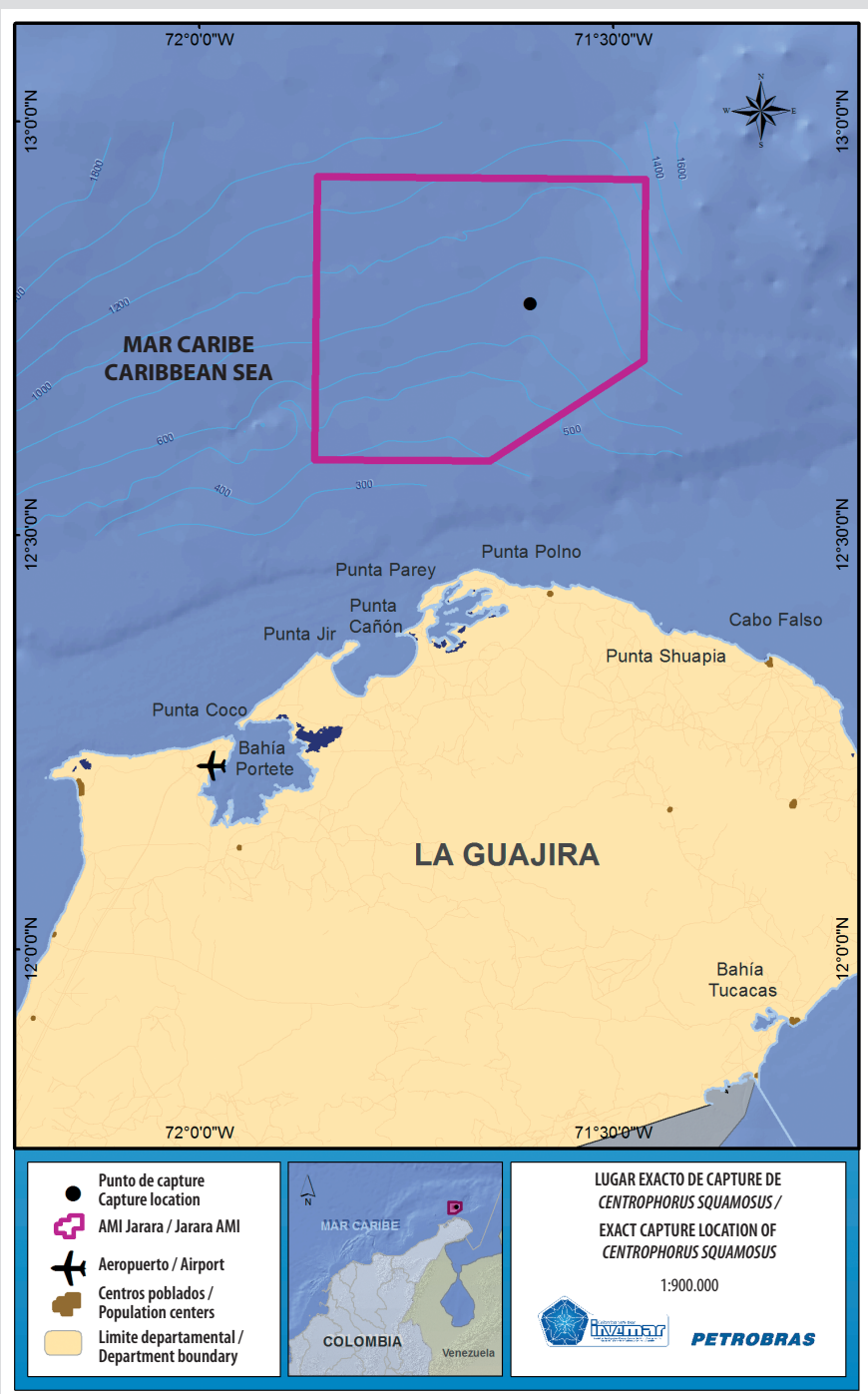

Figura 1. a. Punto de captura de Centrophorus squamosus en el Área de Mayor Interés AMI Jarara. b. Ejemplar de Centrophorus squamosus capturado en el área de estudio. b.

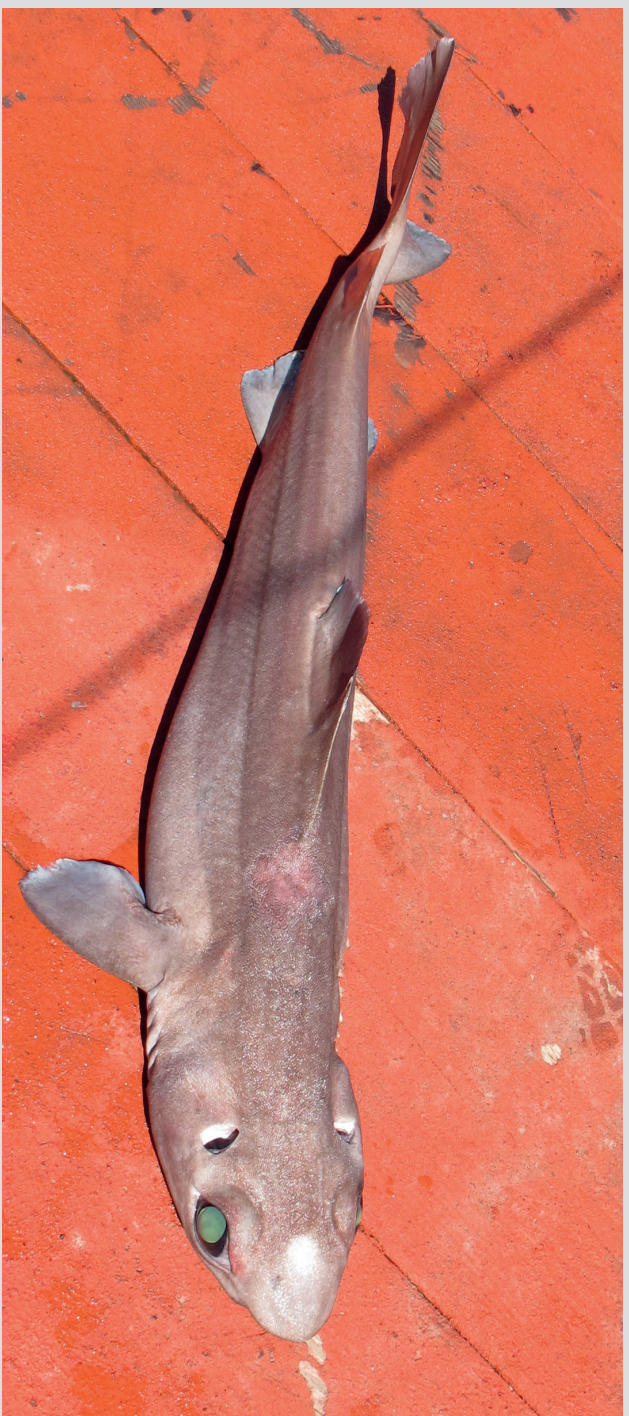

Figure 1. a. Capture location of the Centrophorus squamosus specimen at the Jarara Area (AMI). b. Captured specimen of Centrophorus squamosus. 


\section{RESULTADOS}

\section{Centrophorus squamosus (Bonnaterre, 1788)}

Sinonimias. Squalus squamosus Bonnaterre, 1788; Machephilus dumerili Johnson, 1868; Centrophorus foliaceus Günther, 1877; Lepidorhinus hinbei Tanaka 1918; Centroscymnus fuscus Gilchrist y von Bonde, 1924; Centrophorus nilsoni Thompson, 1930; Encheiridiodon hendersoni Smith, 1967; Centrophorus ferrugineus Meng, Hu \& Li, 1982.

Nombre vernáculo. Quelvacho negro (ESP), Leafscale gulper shark (ING) (Figura 1b).

El ejemplar presenta el hocico moderadamente alargado, rostro comprimido dorsoventralmente con dientes anterolaterales superiores con cúspides erectas a semioblicuas (Figura 2a). Ambas aletas dorsales están precedidas por una espina fuerte, característica sobresaliente para el género (Figura 2b). La altura de la primera aleta dorsal y la longitud de la base (medida desde el origen de la columna anterior) es de 3.6 y $10.3 \%$ de la longitud total, respectivamente. La primera aleta dorsal es más alta que la segunda. El extremo posterior de las aletas pectorales es alargado y puntiagudo, mientras que la esquina interior tiende a ser cuadrada o ligeramente extendida (Figura 3) (Cervigón y Alcalá, 1999).

\section{RESULTS}

Centrophorus squamosus (Bonnaterre, 1788).

Synonyms. Squalus squamosus Bonnaterre, 1788; Machephilus dumerili Johnson, 1868; Centrophorus foliaceus Günther, 1877; Lepidorhinus hinbei Tanaka 1918; Centroscymnus fuscus Gilchrist \& von Bonde, 1924; Centrophorus nilsoni Thompson, 1930; Encheiridiodon hendersoni Smith, 1967; Centrophorus ferrugineus Meng, Hu \& Li, 1982.

Common names. Quelvacho negro (Spanish), Leafscale gulper shark (English) (Figure 1b).

The specimen presents a moderately elongated snout, dorsoventrally compressed face, anterolateral upper teeth with erect to semi-oblique cusps (Figure $2 a)$. Both dorsal fins are preceded by a strong spine, a conspicuous character of the genus (Figure 2b). The height and base length (measured from the origin of the anterior column) of the first dorsal fin are 3.6 and $10.3 \%$ of the total length, respectively. The first dorsal fin is higher than the second. The posterior tips of the pectoral fins are elongated and pointed, whereas the inner corner tends to be square or slightly extended (Figure 3) (Cervigón and Alcalá, 1999).

a.



b.

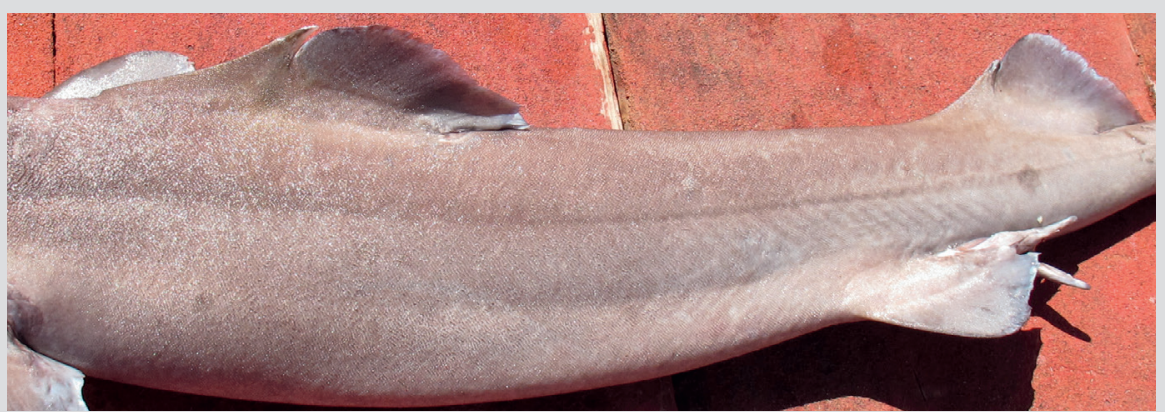

Figura 2. a. Carácter diagnóstico del género, amplitud y oblicuidad de mandíbula superior y diferencia entre los dientes de la mandíbula superior e inferior. b. Carácter diagnóstico de la familia, aletas dorsales con espina en el margen anterior.

Figure 2. a. Diagnostic character of genus Centrophorus: height and obliqueness of the upper jaw showing differences between the teeth of the upper and lower jaws. b. Family-level diagnostic characteristics: spine at the anterior margin of the dorsal fin. 


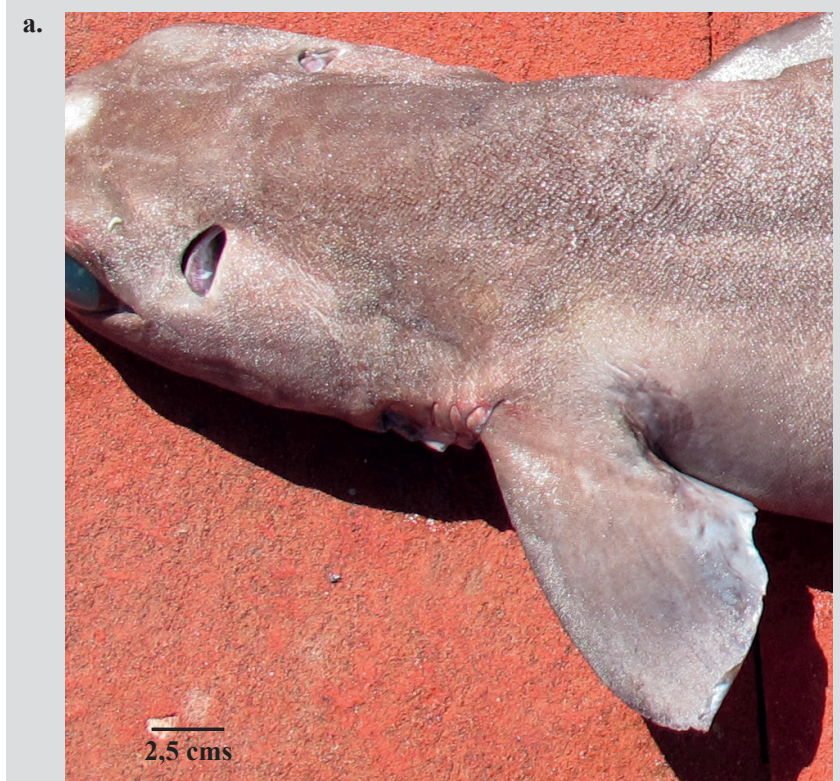

Figura 3. Caracteres diagnósticos para el género, extremo posterior de las pectorales alargado y puntiagudo. b.

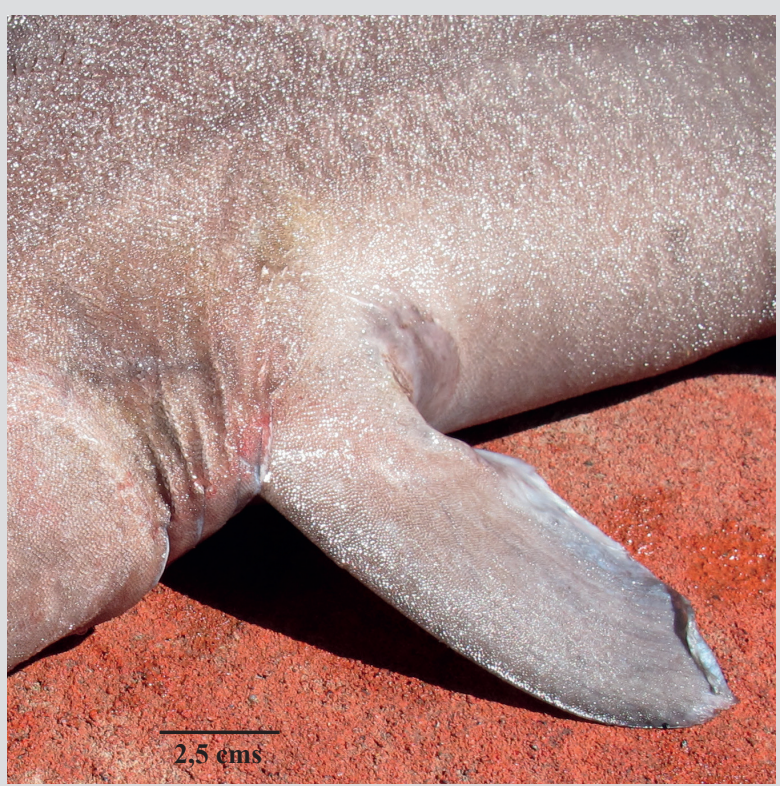

Figure 3. Diagnostic character of genus Centrophorus: posterior tip of the pectoral fins elongated and pointed.
El primer set de dentículos dérmicos en los costados del cuerpo se encuentran superpuestos, presentan pedicelos delgados que elevan coronas planas en forma de hoja. Estas hojas tienen crestas altas y medianas, y una pequeña cresta lateral en cada lado (Cervigón y Alcalá, 1999). Además, en adultos, se evidencian cúspides laterales en los bordes posteriores de los dentículos (Figura 4). El espécimen tiene color gris - café oscuro uniforme.
The first set of dermal denticles on the sides of the body are superposed, with narrow pedicels that raise flat, leaf-like crowns with tall and medium ridges, and a small lateral crest on each side (Cervigón and Alcalá, 1999). In adults, lateral cusps are evident on the posterior edges of the denticles (Figure 4). The specimen presents uniform gray to dark brown coloration. a.

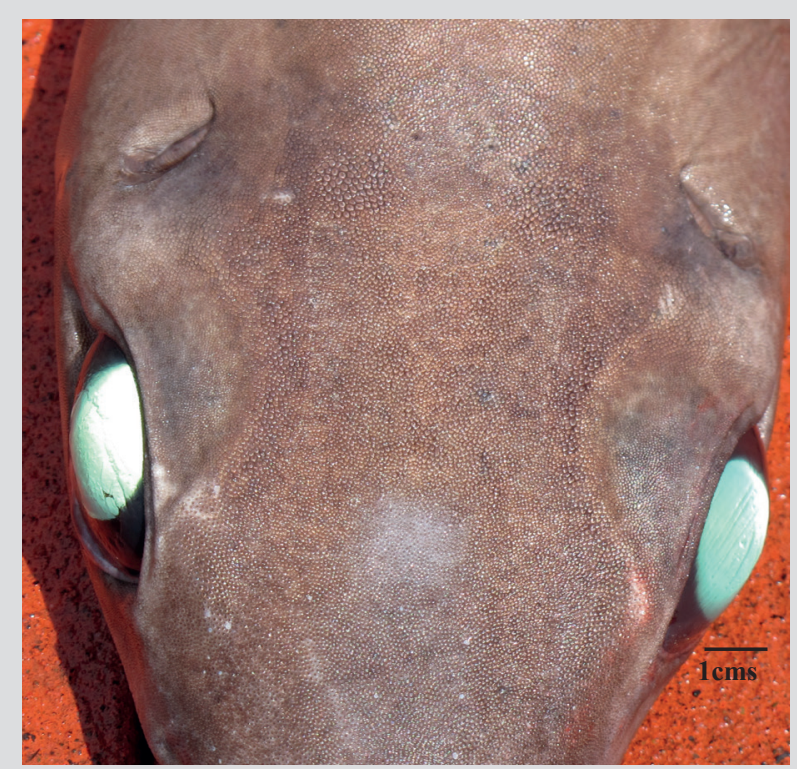

Figura 4. Caracteres diagnósticos, epidermis y forma de dentículos dérmicos. b.

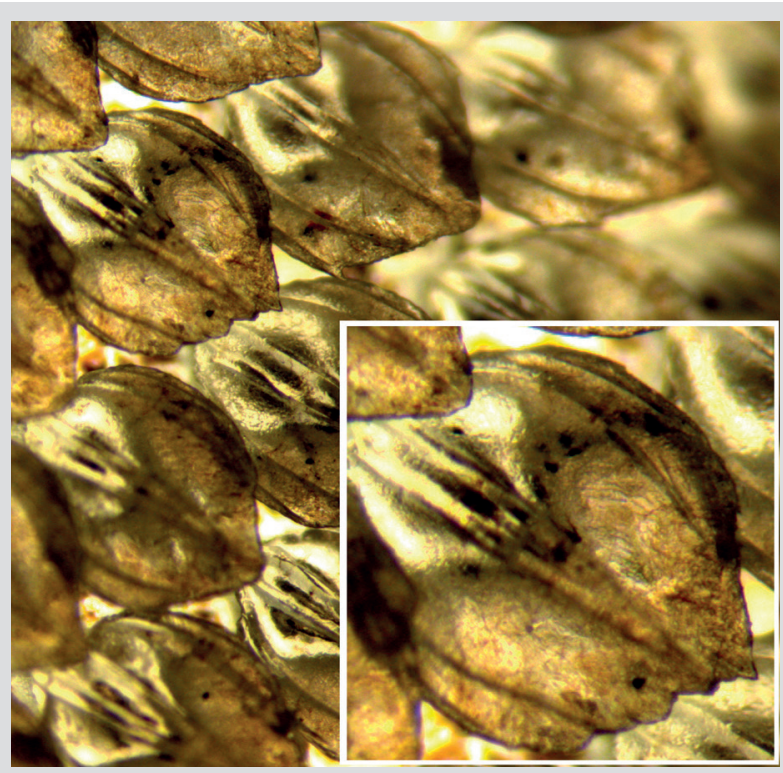

Figure 4. Diagnostic characters: epidermis and shape of dermal denticles. 
El tamaño máximo registrado es de $164 \mathrm{~cm}$, procedente de Indonesia (White et al., 2006); el ejemplar capturado en esta investigación midió $98.2 \mathrm{~cm}$ de longitud total (Tabla 1). La especie se ha registrado entre 145 y $4000 \mathrm{~m}$ de profundidad, tanto en la parte inferior del talud continental como en la parte superior pelágica (Last y Stevens, 1994; Bañon et al., 2006), por lo que se ha considerado bentónico y ocasionalmente mesopelágico (Blache et al., 1970). Presenta dimorfismo sexual en sus dientes, caracterizados por la amplitud y la oblicuidad de la mandíbula superior y el grado de compresión de las coronas de los dientes inferiores (Keyes, 1984) (Figura 2a).

Tabla 1. Caracteres morfométricos de un ejemplar macho de Centrophorus squamosus, capturado en el bloque Tayrona, Área de Interés de Perforación Exploratoria (AIPE) Jarara y referencias de otros autores.
The maximum reported size for this species is $164 \mathrm{~cm}$, from Indonesia (White et al., 2006). The specimen captured in this investigation presented a total length of $98.2 \mathrm{~cm}$ (Table 1). There are occurrence records for this species between 145 and 4,000 m of depth, both in the lower depths of the continental slope and in the upper regions of the pelagic zone (Last and Stevens, 1994; Bañon et al., 2006), and therefore, this shark is considered as benthic and occasionally mesopelagic (Blache et al., 1970). The teeth of this species present sexual dimorphism, characterized by the height and obliqueness of the upper jaw and the degree of compression of the crowns of the lower teeth (Keyes, 1984) (Figure 2a).
Table 1. Morphometric characters of a male specimen of Centrophorus squamosus captured at the Tayrona block, Jarara exploratory drilling area of interest (AIPE), and reference measurements from other authors.

\begin{tabular}{|c|c|c|c|}
\hline $\begin{array}{l}\text { Caracteres morfométricos } \\
\text { Morphometric characteristics }\end{array}$ & $\begin{array}{c}\text { Medidas }(\mathrm{cm}) / \\
\text { Measurements }(\mathrm{cm})\end{array}$ & Garrick (1959) & $\begin{array}{l}\text { Acuña-Marreno et al. } \\
\text { (2013) }\end{array}$ \\
\hline Longitud total (LT) / Total length (TL) & 98.2 & 142 & 95 \\
\hline Longitud horquilla / Fork length & 85.5 & & \\
\hline Longitud precaudal / Precaudal length & 78 & & \\
\hline \multicolumn{4}{|l|}{ Longitud origen segunda dorsal / } \\
\hline Length to the origin of second dorsal fin & 75 & & \\
\hline \multicolumn{4}{|l|}{ Longitud origen primera dorsal / } \\
\hline Length to the origin of first dorsal fin & 32 & & \\
\hline \multicolumn{4}{|l|}{ Longitud espacio interdorsal / } \\
\hline Interdorsal space & 24 & 27.6 & \\
\hline \multicolumn{4}{|l|}{ Longitud entre 2 da aleta dorsal y caudal / } \\
\hline Distance between 2 nd dorsal fin and caudal fin & 7.8 & 5.6 & \\
\hline Longitud cabeza / Head length & 25 & & \\
\hline Longitud prebranquial / Prebranchial length & 20.5 & & \\
\hline Longitud preorbital / Preorbital length & 5.5 & & \\
\hline Longitud prepectoral / Prepectoral length & 25 & & \\
\hline \multicolumn{4}{|l|}{ Longitud entre aletas pectoral y pélvica / } \\
\hline Distance between pectoral and pelvic fins & 35 & 43.5 & \\
\hline Longitud prepélvica / Prepelvic length & 65 & & \\
\hline Diámetro ocular / Eye diameter & 4.5 & 4.2 & \\
\hline Longitud prenarial / Prenarial length & 3.2 & 3.5 & \\
\hline Longitud preoral / Preoral length & 8 & 8.1 & \\
\hline \multicolumn{4}{|l|}{ Longitud margen anterior aleta pectoral / } \\
\hline Length of anterior margin of pectoral fin & 12 & 10.5 & \\
\hline \multicolumn{4}{|l|}{ Longitud altura aleta pectoral / } \\
\hline Height of pectoral fin & 11.7 & & \\
\hline \multicolumn{4}{|l|}{ Longitud base de la pectoral / } \\
\hline Base length of pectoral fin & 6 & & \\
\hline \multicolumn{4}{|l|}{ Longitud margen anterior primera dorsal / } \\
\hline Length of anterior margin of first dorsal fin & 13 & & \\
\hline
\end{tabular}




\begin{tabular}{|c|c|c|c|}
\hline $\begin{array}{l}\text { Caracteres morfométricos } \\
\text { Morphometric characteristics }\end{array}$ & $\begin{array}{l}\text { Medidas }(\mathrm{cm}) / \\
\text { Measurements }(\mathrm{cm})\end{array}$ & Garrick (1959) & $\begin{array}{l}\text { Acuña-Marreno et al. } \\
\text { (2013) }\end{array}$ \\
\hline \multicolumn{4}{|l|}{ Longitud margen posterior primera dorsal/ } \\
\hline Length of posterior margin of first dorsal fin & 3.5 & 3.7 & \\
\hline Longitud base primera dorsal / Base length of first dorsal fin & 17 & 9.9 & \\
\hline \multicolumn{4}{|l|}{ Longitud margen anterior segunda dorsal / } \\
\hline Length of anterior margin of second dorsal fin & 9 & & \\
\hline Longitud base segunda dorsal /Base length of second dorsal fin & 13 & 4 & \\
\hline Longitud aleta pélvica / Length of pelvic fin & 8 & & \\
\hline \multicolumn{4}{|l|}{ Longitud margen anterior aleta pélvica / } \\
\hline Length of anterior margin of pelvic fin & 7 & & \\
\hline Longitud base aleta pélvica / Base length of pelvic fin & 7.5 & & \\
\hline \multicolumn{4}{|l|}{ Longitud margen interno aleta pélvica / } \\
\hline Length of inner margin of pelvic fin & 3.5 & 4.9 & \\
\hline \multicolumn{4}{|l|}{ Longitud margen posterior aleta pélvica / } \\
\hline Length of posterior margin of pelvic fin & 9 & & \\
\hline $\begin{array}{l}\text { Longitud margen dorsal aleta caudal /Length of dorsal margin of } \\
\text { caudal fin }\end{array}$ & 19 & & \\
\hline \multicolumn{4}{|l|}{ Longitud margen preventral aleta caudal / } \\
\hline Length of preventral margin of caudal fin & 11.5 & & \\
\hline \multicolumn{4}{|l|}{ Longitud margen subterminal aleta caudal / } \\
\hline Length of subterminal margin of caudal fin & 2.7 & & \\
\hline $\begin{array}{l}\text { Longitud margen terminal aleta caudal / Length of terminal margin } \\
\text { of caudal fin }\end{array}$ & 6.5 & & \\
\hline Longitud lóbulo aleta caudal / Length of lobe of caudal fin & 14.5 & & \\
\hline Longitud interna clásper / Internal length of clasper & 13.5 & & \\
\hline
\end{tabular}

Generalmente las hembras maduran a $125 \mathrm{~cm}$ y los machos a $101 \mathrm{~cm}$, son ovovivíparos (Compagno y Niem, 1998). Se alimenta de peces óseos, cefalópodos, crustáceos y quimeras (Compagno, 2002).

Su distribución abarca en el Atlántico oriental: Islandia y Mar del Norte (George, 2009), mar Mediterráneo (Whitehead et al., 1984; Bañon et al., 2006), plataforma atlántica de Senegal, Feroés, Madeira, Azores (Arruda, 1997), Gabón, República Democrática del Congo, Namibia (Bianchi et al., 1993), Sur África (Bass et al., 1986; MuñozChápuli y Ramos, 1989; Compagno et al., 1991). En el océano Índico occidental: islas de Aldabra, Almirantes, mar Arábico y Sri Lanka (Morón et al., 1999; Baranes, 2003; Manilo y Bogordsky, 2003). En el océano Índico central: India (Akhilesh et al., 2010), Islas Maldivas (Adam et al., 1998). En el Pacífico occidental: Japón (Masuda et al., 1984; Nakabo, 2000; Shinohara et al., 2001), Filipinas (Compagno et al., 2005), China (Randall y Lim, 2000), Australia (Hutchins, 2001; White, 2008) y Nueva Zelanda (Garrick, 1959; Paulin et al., 1989; Paxton et al., 1989; Amaoka et
Generally the females mature to $125 \mathrm{~cm}$, and males $101 \mathrm{~cm}$. Reproduction is ovoviviparous (Compagno and Niem, 1998). Their diet consists of bony fish, cephalopods, crustaceans and chimaeras (Compagno, 2002).

The distribution of C. squamosus covers the eastern Atlantic (Springer, 1990), Iceland and the North Sea (George, 2009), the Mediterranean Sea (Whitehead et al., 1984, Bañon et al., 2006), the Atlantic platform in Senegal, Faroese, Madeira, Azores (Arruda, 1997), Gabon, Democratic Republic of the Congo, Namibia (Bianchi et al., 1993) and South Africa (Bass et al., 1986; Muñoz-Chápuli and Ramos, 1989; Compagno et al., 1991); in the western Indian Ocean, the islands of Aldabra, Almirantes, Arabian Sea and Sri Lanka (Morón et al., 1999; Baranes, 2003; Manilo and Bogordsky, 2003); in the central Indian Ocean, India (Akhilesh et al., 2010) and Maldives Islands (Adam et al., 1998); and in the western Pacific, Japan (Masuda et al., 1984; Nakabo, 2000; Shinohara et al., 2001), Philippines (Compagno et al., 2005), China (Randall and Lim, 2000), Australia (Hutchins, 2001; White, 2008) and New Zealand (Garrick, 1959; Paulin et 
al., 1990; Last y Stevens, 1994). Esta localización permite describir al taxón con una generalizada forma de distribución bipolar, en aguas templadas (Compagno, 1984) (Figura 5). Este hallazgo es el primer registro con evidencia física que confirma la presencia de esta especie (C. squamosus) en el Caribe, tras los ejemplares referidos para la costa de Venezuela, de los que tanto Cervigón y Alcalá (1999) como Compagno (2002) cuestionan su correcta identificación. (Figura 6). al., 1989; Paxton et al., 1989; Amaoka et al., 1990; Last and Stevens, 1994). This distribution allows to describe the taxon with a generalized form of bipolar distribution, in temperate waters (Compagno, 1984) (Figure 5). The present finding is the first record with physical evidence that confirms the presence of this species (C. squamosus) in the Caribbean, after the specimens cited off the Venezuelan coast, for which both Cervigón and Alcalá (1999) and Compagno (2002) questioned the identification (Figure 6).

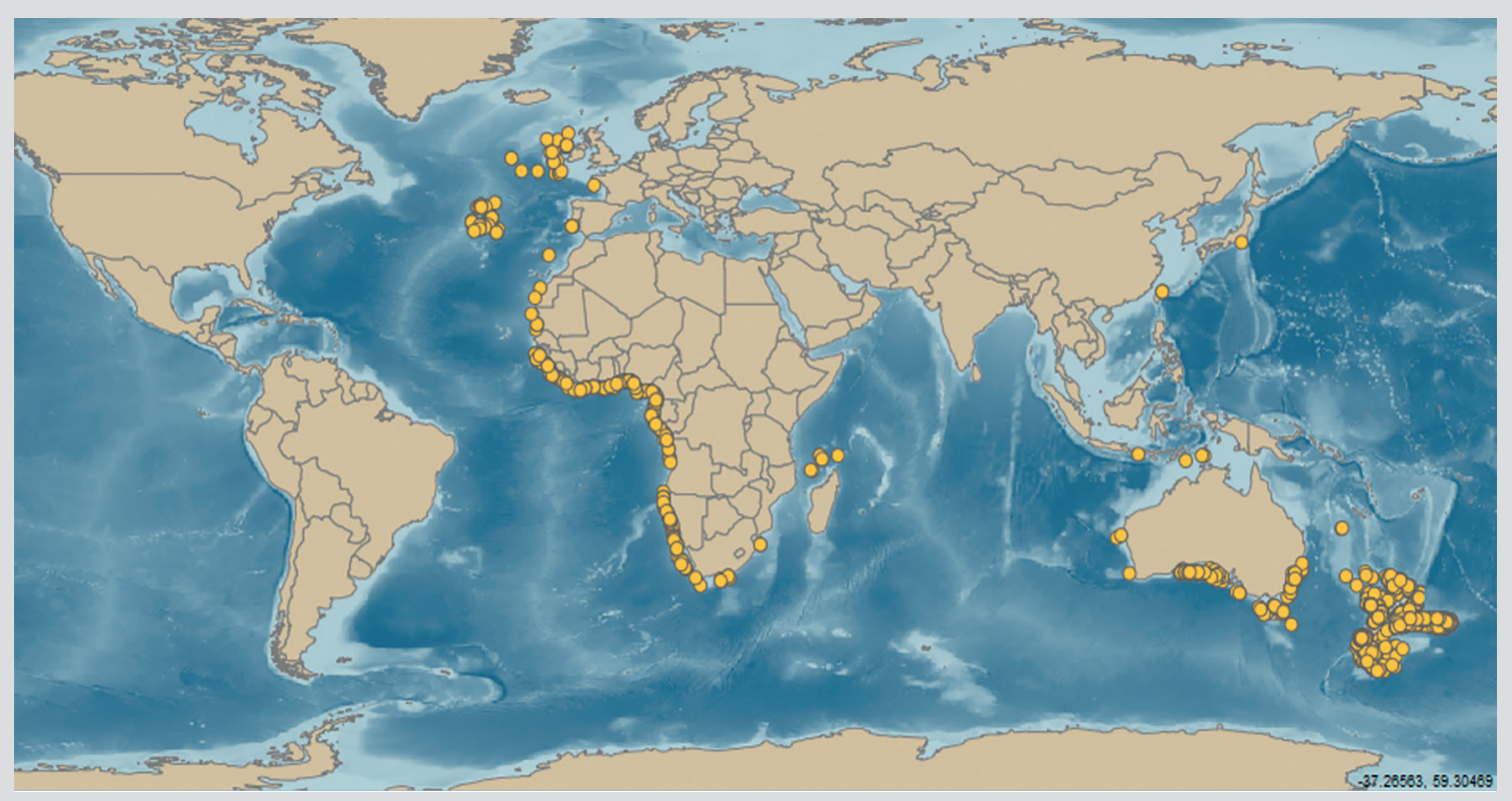

Figura 5. Mapa con las localidades donde se ha encontrado Centrophorus squamosus a nivel mundial (Sutton et al., 2017).

Figure 5. Map of worldwide localities of Centrophorus squamosus occurrence records (Sutton et al., 2017).

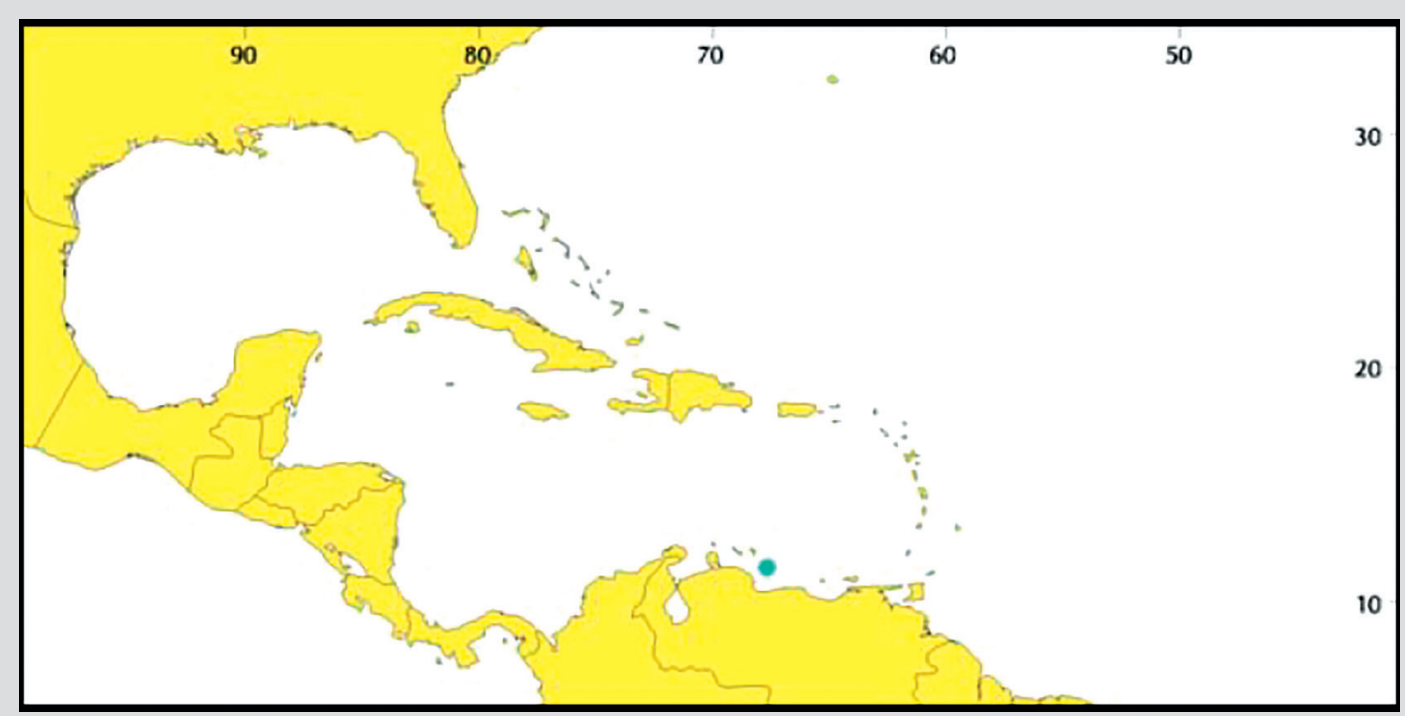

Figura 6. Localidad donde se ha registrado Centrophorus squamosus en el mar Caribe (Carpenter, 2002).

Figure 6. Location of Centrophorus squamosus records for the Caribbean Sea (Carpenter, 2002). 
En el océano Atlántico nororiental C. squamosus es capturado usualmente con palangre, debido a la profundidad que habita. Se consume salado y se emplea en la producción de harina de pescado (Bañon et al., 2006). La carne y las aletas tienen un bajo valor, mientras que el aceite de su hígado y en ocasiones sus óvulos maduros poseen un alto valor (Bañon et al., 2006). Es una especie considerada vulnerable según la lista roja de especies amenazadas (IUCN, 2013).

\section{AGRADECIMIENTOS}

Se agradece a la Empresa Petrobras Colombia Ltd. y el Invemar, por el apoyo logístico y financiero de esta investigación (proyecto No. CSC 007-012); a H. Sáenz y todas aquellas personas que participaron en la colecta del material biológico y en la salida de campo, especialmente al biólogo L. Mejía, al ingeniero pesquero F. Herrera y los auxiliares J. Asís y H. Asís. También a la tripulación de la M/N Don Rodrigo.
In the northeastern Atlantic Ocean, C. squamosus is usually caught with longlines, due to the depth that it inhabits. C. squamosus is consumed salted and used in the production of fishmeal (Bañon et al., 2006). The meat and fins have low market value, whereas the liver oil and mature eggs may reach a higher value (Bañon et al., 2006). This species is considered vulnerable according to the red list of threatened species (IUCN, 2013).

\section{ACKOWLEDGEMENTS}

The authors thank Petrobras Colombia Ltd. and Invemar for logistic and financial support (project CSC 007-012). We also thank H. Sáenz and everyone that participated in the collection of biological material and field work, especially biologist L. Mejía, fisheries engineer F. Herrera, assistants J. Asís and H. Asís, and the crew of M/N Don Rodrigo.

\section{BIBLIOGRAFÍA / LITERATURE CITED}

Adam, M.S., N. R. Merrett and R.C. Anderson. 1998. Additions to the fish fauna of the Maldive Islands. Part 1: An annotated checklist of the deep demersal fishes of the Maldive Islands. Ichthyol. Bull. J. L. B. Smith Inst. Ichthyol., (67): 1-19.

Akhilesh, K.V., M. Hashim, K.K. Bineesh, C.P.R. Shanis and U. Ganga. 2010. New distributional records of deep-sea sharks from Indian waters. J. Mar. Biol. Ass. India, 52 (1): 29-34.

Amaoka, K. 1983. Fishes from the northeastern Sea of Japan and the Okhotsk Sea off Hokkaido. Japan Fish. Res. Cons. Assoc. Tokyo. 371 p.

Amaoka, K., K. Matsuura, T. Inada, M. Takeda, H. Hatanaka, K. Okada (Eds). 1990. Fishes collected by the R/V Shinkai Maru around New Zealand. Japan Marine Fishery Resource Research Center, Tokyo, Japan. 410 p.

Arruda, L.M. 1997. Checklist of the marine fishes of the Azores. Arq. Mus. Bocage. N.S., 3 (2): 13-162.

Bañon, R., C. Piñeiro and M. Casas. 2006. Biological aspects of deep-water sharks Centroscymnus coelolepis and Centrophorus squamosus in Galicia waters (northwestern Spain). J. Mar. Biol. Ass., 86: 843-846.

Baranes, A. 2003. Sharks from the Almirantes Islands, Seychelles, with a description of two new species of squaloids from the deep sea. Isr. J. Zool., 49: 33-65.

Bass, A.J., L.J.V. Compagno and P.C. Heemstra. 1986. Family Squalidae No. 5: 49-62. In: Smith, M.M. and P.C. Heemstra (Eds.). Smiths' sea fishes. Macmillan, Johannesburg. 1047 p.

Bianchi, G., K.E. Carpenter, J.P. Roux, F.J. Molloy, F.J. Boyer and H.J. Boyer. 1993. FAO species identification field guide for fisheries purposes. The living marine resources of Namibia. FAO, Rome. 250 p.

Blache, J., J. Cadenat and A. Stauch. 1970. Clés de détermination des poissons de mer signalés dans l'Atlantique Oriental (entre le 20e parallèle N. et le 15e parallèle S.). Faune Tropicale, 18: 479 p.

Bonnaterre, J.P. 1788. Ichthyologie. Tableau encyclopédique et méthodique des trois règnes de la Nature. Paris. 215 p.

Carpenter, K.E. 2002. The living marine resources of the Western Central Atlantic FAO species identification guide for fishery purposes and American Society of Ichthyologists and Herpetologists Special Publication No. 5. Rome. 1:600 p.

Cervigón, F. y A. Alcalá. 1999. Los peces marinos de Venezuela. Tiburones y rayas. Fundación Museo del Mar, Caracas. 5:230 p.

Compagno, L.J.V. 1973. Interrelationships of living elasmobranchs. J. Linn. Soc. Zool., 53 (Suppl 1): 15-61.

Compagno, L.J.V. 1984. FAO species catalogue. Sharks of the world. An annotated and illustrated catalogue of sharks species known to date. Part 1. Hexanchiformes to Lamniformes. FAO Fish. Synop., 125 (4): 1-249. 
Compagno, L.J.V. 2002. Sharks: 357-505. In: Carpenter, K.E. (Ed.). The living marine resources of the Western Central Atlantic. Introduction, molluscs, crustaceans, hagfishes, sharks, baroid fishes, and chimaeras. FAO Species Ident. Guide Fish. Purp., Am. Soc. Ichthyol. Herpetol. Spec. Publ., 1(5): $599 \mathrm{p}$.

Compagno, L.J.V. and V.H. Niem. 1998. Squalidae. Dogfish sharks: 1213-1232. In: Carpenter, K.E. and V.H. Niem (Eds.). FAO identification guide for fishery purposes. The living marine resources of the western central Pacific. Vol. 2. Rome. 1396 p.

Compagno, L.J.V., D.A. Ebert and P.D. Cowley. 1991. Distribution of offshore demersal cartilaginous fish (Class Chondrichthyes) off the west coast of southern Africa, with notes on their systematics. SA J. Mar. Sci., 11: 43-139.

Compagno L.J.V., P.R. Last, J.D. Stevens and M.N.R. Alava. 2005. Checklist of Philippine Chondrichthyes. CSIRO Mar. Lab. Rep., $243: 103$ p.

Garrick, J.A.F. 1959. Studies on New Zealand Elasmobranchii Part VII. The identity of specimens of Centrophorus from New Zealand. Trans. Roy. Soc., 86 (1): $127-141$.

George, M.R. 2009. An annotated checklist of North Sea cartilaginous fish species. J. Appl. Ichthyol., 25 (Supplement 1): 33-39.

Hutchins, J.B. 2001. Checklist of the fishes of Western Australia. Rec. West. Aust. Mus., Suppl. 63: 9-50.

IUCN. 2013. IUCN Red List of Threatened Species. Version 2013.2. www.iucnredlist.org. 15/05/2014.

Keyes, I.W. 1984. New records of fossil elasmobranch genera Megascyliorhinus, Centrophorus, and Dalatias (Order Selachii) in New Zealand. NZ J. Geol. Geoph., 27 (2): 203-216.

Krefft, G. and E. Tortonese. 1973a. Oxynotidae: 35-36. In: Hureau, J. C. and T. Monod (Eds.). Checklist of the fishes of the northeastern Atlantic and of the Mediterranean. Unesco, Vol. 1. Paris. 681 p.

Krefft, G. and E. Tortonese. 1973b. Squalidae: 37-48. En: Hureau, J. C. and T. Monod (Eds.). Checklist of the fishes of the northeastern Atlantic and of the Mediterranean. Unesco, Vol. 1. Paris. 681 p.

Last, P.R. and J.D. Stevens. 1994. Sharks and rays of Australia. CSIRO, Melbourne. 513 p.

Manilo, L.G. and S.V. Bogorodsky. 2003. Taxonomic composition, diversity and distribution of coastal fishes of the Arabian Sea. J. Ichthyol., 43 (Suppl. 1): $75-149$

Masuda, H., K. Amaoka, C. Araga, T. Uyeno and T. Yoshino. 1984. The fishes of the Japanese Archipelago. Tokai University Press, Tokyo. 437 p.

Morón, J., B. Bertrand and P. R. Last. 1999. A checklist of sharks and rays of western Sri Lanka. J. Mar. Biol. As. India, 40 (1-2): 142-157.

Muñoz-Chápuli, R. and F. Ramos. 1989. Review of the Centrophorus sharks (Elasmobranchii, Squalidae) of the eastern Atlantic. Cybium, 13 (1): 65-81.

Nakabo, T. (Ed.). 2000. Fishes of Japan with pictorial keys to the species. Vol. 1. 2nd ed. Tokai University Press, Tokyo. 866 p.

Paulin, C. D., A. Stewart, C.D. Roberts and P.J. McMillan. 1989. New Zealand fish a complete guide. Nat. Mus. NZ. Misc. Se., 19: 279 p.

Paxton, J. R., D.F. Hoese, G.R. Allen and J.E. Hanley. 1989. Zoological catalogue of Australia. Vol. 7. Pisces. Petromyzontidae to Carangidae. Austr. Gov. Publ. Serv., Canberra. 665 p.

Randall, J.E. and K.K.P. Lim. 2000. A checklist of the fishes of the South China Sea. Raffles Bull. Zool., (Suppl. 8): 569-667 p.

Shinohara, G., H. Endo, K. Matsuura, Y. Machida and H. Honda. 2001. Annotated checklist of the deepwater fishes from Tosa Bay, Japan. Mon. Nat. Sci. Mus. Tokyo, (20): 283-343.

Springer, S. 1990. Squalidae: 7-19. In: Quéro, J.C., J.C. Hureau, C. Karrer, A. Post and L. Saldanha. Checklist of the fishes of the eastern tropical Atlantic. Three Vols. Clofeta, Unesco, Paris. 1492 p.

Sutton, T.T., M.R. Clark, D.C. Dunn, P.N. Halpin, A.D. Rogers, J. Guinotte, S.J. Bograd, M.V. Ángel, J.A.A. Pérez, K. Wishner, R.L. Haedrich, D.J. Lindsay, J.C. Drazen, A. Vereshchaka, U. Piatkowski, T. Morato, K. Błachowiak-Samołyk, B.H. Robison, K.M. Gjerde, A. Pierrot-Bults, P. Bernal, G. Reygondeau and M. Heino. 2017. A global biogeographic classification of the mesopelagic zone. Deep Sea Res. I, 126: 85-102. https://doi. org/10.1016/j.dsr.2017.05.006

White, W.T. 2008. Various elasmobranch family accounts: 32-100. In: Gomon, M.F., D.J. Bray and R. Kuiter (Eds.). Fishes of Australia's southern coast. New Holland Publishers, Melbourne. 928 p.

White, W.T., P.R. Last, J.D. Stevens and G.K. Yearsley. 2006. Economically important sharks and rays of Indonesia. Aust. Centre Internat. Agric. Res., Canberra. 329 p.

Whitehead, P.J.P., M.L. Bauchot, J.C. Hureau, J.G. Nielsen and E. Tortonese. 1984. Fishes of the northeastern Atlantic and the Mediterranean. Vol. 1. Unesco, Paris. 510 p. 